\title{
Growth curves in Down syndrome with congenital heart disease
}

\author{
Caroline D'Azevedo Sica ${ }^{1}$, Claudia Ciceri Cesa ${ }^{2}$, lucia Campos Pellanda ${ }^{3 *}$ \\ ${ }^{1}$ MSc in Health Sciences - Nutritionist at the Instituto de Cardiologia / Fundação Universitária de Cardiologia (IC/FUC), Porto Alegre, RS, Brazil \\ ${ }^{2} \mathrm{PhD}$ in Health Sciences - Professor of Physical Education at the IC/FUC, Porto Alegre, RS, Brazil \\ ${ }^{3} \mathrm{PhD}$ in Cardiovascular Sciences - Pediatric Cardiologist at the IC/FUC, Porto Alegre, RS, Brazil
}

Study conducted at the Instituto de Cardiologia/Fundação Universitária de Cardiologia (IC/FUC), Porto Alegre, RS, Brazil

Article received: $4 / 1 / 2015$ Accepted for publication: 11/8/2015

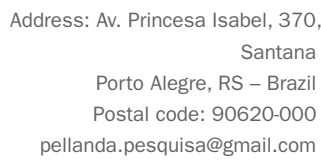

\section{SUMMARY}

Introduction: To assess dietary habits, nutritional status and food frequency in children and adolescents with Down syndrome (DS) and congenital heart disease (CHD). Additionally, we attempted to compare body mass index (BMI) classifications according to the World Health Organization (WHO) curves and curves developed for individuals with DS.

Method: Cross-sectional study including individuals with DS and CHD treated at a referral center for cardiology, aged 2 to 18 years. Weight, height, BMI, total energy and food frequency were measured. Nutritional status was assessed using BMI for age and gender, using curves for evaluation of patients with DS and those set by the WHO.

Results: 68 subjects with DS and CHD were evaluated. Atrioventricular septal defect (AVSD) was the most common heart disease (52.9\%). There were differences in BMI classification between the curves proposed for patients with DS and those proposed by the WHO. There was an association between consumption of vitamin $\mathrm{E}$ and polyunsaturated fatty acids.

Conclusion: Results showed that individuals with DS are mostly considered normal weight for age, when evaluated using specific curves for DS. Reviews on specific curves for DS would be the recommended practice for health professionals so as to avoid precipitated diagnosis of overweight and/or obesity in this population.

Keywords: Down syndrome, assessment of nutritional status, anthropometry, body mass index.

\section{INTRODUCTION}

Obesity, which in 2012 affected 43,000 worldwide, is an important cardiovascular risk factor. ${ }^{1}$ Approximately $30 \%$ of the children with Down syndrome (DS) are considered obese according to the World Health Organization (WHO). ${ }^{2,3}$ In 2002, growth curves for individuals with DS were proposed by Myrelid et al. ${ }^{4}$

Heart disease occurs in 40 to $50 \%$ of patients with DS and contributes significantly to morbidity and mortality in these cases. ${ }^{5}$ However, little is known about the prevalence of obesity in young people with DS associated with heart disease/congenital heart disease (CHD). ${ }^{6,7}$

If, on the one hand, heart diseases increase the risk of malnutrition before surgical correction, on the other hand, the overprotection of parents and physical inactivity can aggravate obesity often presented by patients with DS after surgical correction. ${ }^{5,8}$
From the perspective of epidemiology in the course of life, risk factors that occur at different stages of development can have an impact on cardiovascular health throughout life. Malnutrition followed by overweight and obesity may represent an enhancement of risk to cardiovascular health compared to maintaining the same nutritional status over a period of time. ${ }^{7,9}$ Children with DS and CHD, due to the characteristics mentioned above, can serve as a model for the study of this phenomenon.

Moreover, the growth and development curves used in studies evaluate patients with DS based on weight and length/height according to age and gender. Despite the indication of these specific distributions, currently the body mass index (BMI) for age is considered as a reference by the WHO for the diagnosis of overweight and obesity in adolescents in the general population. ${ }^{10}$ 
Therefore, the aim of this study was to evaluate dietary habits, nutritional status and food frequency in children and adolescents with DS and congenital heart disease. Additionally, he sought to compare the BMI classifications according to the curves of the $\mathrm{WHO}^{11}$ and the curves developed for individuals with DS in this particular group. ${ }^{4}$

\section{Method}

Cross-sectional study conducted from May 2011 to December 2012, including children and adolescents aged from 2 to 18 years with Down syndrome and congenital heart disease seen at the Pediatric Cardiology Clinic, Instituto de Cardiologia.

The project was approved by the ethics committee of Instituto de Cardiologia do Rio Grande Sul, under application $n^{\circ} 4458 / 10$. The participants' parents and/or legal guardians signed prior authorization consenting to participate in the research.

A questionnaire with information about family history was applied for analysis of non-communicable diseases, indicating the degree of kinship (father, mother, grandparents and siblings).

Weight and height were measured in a anthropometric scale for adults (with $150 \mathrm{~kg}$ capacity and $100 \mathrm{~g}$ precision) with coupled stadiometer (maximum length 2 meters and accuracy of $0.5 \mathrm{~cm}$ ). Nutritional status was analyzed using BMI for age and gender, using the curves for evaluation of individuals with DS recommended by Myrelid et al. ${ }^{4}$ and the curves proposed by the WHO. ${ }^{11}$ The participants were classified as underweight, normal weight, overweight and obesity.

The eating habits of the participants were assessed using a food frequency questionnaire used in other work with children. ${ }^{12}$ For diet assessment, we used a 24 -hour record, referring to food intake the day before consultation, and Nutwin software for the analysis of the records. Macro- and micronutrients were evaluated based on the 24-hour record and according to the Dietary Reference Intakes (DRI) recommendations. ${ }^{13}$

Diet composition was analyzed in terms of energy composition, carbohydrates, lipids, proteins, vitamins A, $\mathrm{C}, \mathrm{D}$ and $\mathrm{E}$, calcium, iron and fatty acids, according to the recommendations of the DRI by gender and age. The percentage distribution of macronutrients was evaluated according to the amounts proposed by the Institute of Medicine. ${ }^{13}$

Considering a proportion of $50 \%$ of children with risk factors, with margin of error of 0.8 and a $95 \%$ confidence level, we estimated that it would be necessary to study 131 patients. Prevalence was described as percentages with their respective $95 \%$ confidence intervals. Continuous variables were described as means and standard deviations. Macronutrient intake was compared between the groups using Student's t-test. The analyses were performed with Statistical Package for the Social Sciences (SPSS) software, version 19.0 for Windows, and a p-value $<0.05$ was considered significant.

\section{Results}

Of the 70 children and adolescents with DS and congenital heart disease potentially eligible during the study period, there were two whose parents did not consent to participate. The final sample thus included 68 participants. The general characteristics of the participants are presented in Table 1.

TABLE 1 Description of the general characteristics and congenital heart diseases in the studied population $(n=68)$. Variable Overall n (\%)

\begin{tabular}{ll}
\hline Age $($ years - mean \pm SD $)$ & $9.29 \pm 4.88$ \\
\hline Gender & \\
\hline Female & $36(52.9)$ \\
\hline Male & $32(47.1)$ \\
\hline Heart diseases & $36(52.9)$ \\
\hline Atrioventricular septal defect & $25(36.8)$ \\
\hline Interventricular communication & $23(33.8)$ \\
\hline Interatrial communication & $14(20.6)$ \\
\hline Persistent arterial duct & $10(14.7)$ \\
\hline Tetralogy of Fallot & $7(10.3)$ \\
\hline Tricuspid insufficiency & $6(8.8)$ \\
\hline Pulmonary stenosis & $5(7.4)$ \\
\hline Mitral insufficiency & $3(4.4)$ \\
\hline Patent foramen ovale & $9(13.3)$ \\
\hline Other & \\
\hline
\end{tabular}

SD: standard deviation.

Atrioventricular septal defect (AVSD) was the most common heart disease $(52.9 \%)$, and $47.1 \%$ were male. There were differences in BMI classification (underweight, normal weight, overweight and obesity) between the curves proposed for people with DS and the curves proposed by the WHO (Table 2).

Adequate intake of carbohydrates, proteins and lipids was achieved by $66.2,94.1$ and $41.2 \%$ of participants, respectively. As for the intake of micro- and macronutrients, there was an association between vitamin $\mathrm{E}$ and polyunsaturated fatty acids (Table 3). 
TABLE 2 Comparison of anthropometric assessment using BMI curves for normal individuals and for individuals with Down syndrome.

BMI for normal individuals

\begin{tabular}{|c|c|c|c|c|c|c|}
\hline & & $\begin{array}{l}\text { Low weight } \\
\mathrm{N}=1 \\
\mathrm{n}(\%)\end{array}$ & $\begin{array}{l}\text { Normal weight } \\
\mathrm{N}=34 \\
\text { n (\%) }\end{array}$ & $\begin{array}{l}\text { Overweight } \\
N=17 \\
\text { n (\%) }\end{array}$ & $\begin{array}{l}\text { Obese } \\
N=16 \\
n(\%)\end{array}$ & $\mathrm{p}<0.01$ \\
\hline \multirow[t]{4}{*}{$\begin{array}{l}\text { BMI for individuals } \\
\text { with Down syndrome }\end{array}$} & $\begin{array}{l}\text { Low weight } \\
N=6 \\
\text { n (\%) }\end{array}$ & $1(100)$ & $5(14.7)$ & $0(-)$ & $0(-)$ & \\
\hline & $\begin{array}{l}\text { Normal weight } \\
\mathrm{N}=44 \\
\mathrm{n}(\%)\end{array}$ & $0(-)$ & $29(85.3)$ & $14(82.4)$ & $1(6.3)$ & \\
\hline & $\begin{array}{l}\text { Overweight } \\
N=8 \\
\text { n (\%) }\end{array}$ & $0(-)$ & $0(-)$ & $3(17.6)$ & $5(31.3)$ & \\
\hline & $\begin{array}{l}\text { Obese } \\
\mathrm{N}=10 \\
\mathrm{n}(\%)\end{array}$ & $0(-)$ & $0(-)$ & $0(-)$ & $10(62.5)$ & \\
\hline
\end{tabular}

BMI: body mass index.

TABLE 3 Intake of macro- and micronutrients in 24 hours record.

\begin{tabular}{|c|c|c|c|c|c|c|}
\hline Nutrient & $\begin{array}{l}\text { Overall } \\
\text { Mean } \pm S D\end{array}$ & $\begin{array}{l}\text { Low weight }(n=6) \\
\text { Mean } \pm S D\end{array}$ & $\begin{array}{l}\text { Normal weight }(n=44) \\
\text { Mean } \pm \text { SD }\end{array}$ & $\begin{array}{l}\text { Overweight }(n=8) \\
\text { Mean } \pm \text { SD }\end{array}$ & $\begin{array}{l}\text { Obesity }(n=10) \\
\text { Mean } \pm \text { SD }\end{array}$ & p-value \\
\hline \multicolumn{7}{|l|}{ Macronutrients } \\
\hline TEV $(\mathrm{kcal})$ & $1882.82 \pm 495.16$ & $1664.67 \pm 347.76$ & $1878.43 \pm 443.82$ & $2218.25 \pm 806.70$ & $1764.10 \pm 407.13$ & 0.143 \\
\hline Carbohydrates (\%) & $54.45 \pm 11.35$ & $58.51 \pm 10.04$ & $52.91 \pm 12.33$ & $59.13 \pm 9.01$ & $55.01 \pm 8.49$ & 0.406 \\
\hline Protein (\%) & $17.50 \pm 4.48$ & $16.92 \pm 2.86$ & $17.13 \pm 4.36$ & $19.39 \pm 4.26$ & $17.92 \pm 5.99$ & 0.600 \\
\hline Lipids (\%) & $27.17 \pm 8.93$ & $24.56 \pm 9.14$ & $28.58 \pm 8.60$ & $21.47 \pm 9.50$ & $27.05 \pm 8.99$ & 0.182 \\
\hline \multicolumn{7}{|l|}{ Micronutrients } \\
\hline Fiber (g) & $19.89 \pm 9.65$ & $14.34 \pm 2.71$ & $20.30 \pm 8.98$ & $24.76 \pm 13.59$ & $17.52 \pm 10.56$ & 0.196 \\
\hline Calcium (mg) & $1126.06 \pm 963.72$ & $1101.40 \pm 628.86$ & $1081.47 \pm 880.43$ & $1672.80 \pm 1645.49$ & $899.63 \pm 743.03$ & 0.364 \\
\hline Iron (mg) & $14.81 \pm 6.58$ & $13.40 \pm 8.72$ & $13.90 \pm 5.00$ & $19.20 \pm 6.35$ & $16.13 \pm 10.24$ & 0.166 \\
\hline Sodium (mg) & $1626.72 \pm 940.93$ & $869.36 \pm 445.24$ & $1651.08 \pm 917.06$ & $1916.69 \pm 1024.22$ & $1741.98 \pm 1082.61$ & 0.185 \\
\hline Zinc (mg) & $10.37 \pm 4.08$ & $7.79 \pm 3.70$ & $10.22 \pm 4.19$ & $11.96 \pm 3.41$ & $11.27 \pm 3.97$ & 0.248 \\
\hline Vitamin A (RE) & $749.90 \pm 1037.9$ & $752.22 \pm 745.53$ & $681.07 \pm 801.83$ & $701.17 \pm 1008.49$ & $1090.33 \pm 1921.80$ & 0.741 \\
\hline Vitamin E (aTE) & $5.12 \pm 2.38$ & $3.51 \pm 1.98$ & $5.44 \pm 2.02$ & $3.50 \pm 1.97$ & $5.97 \pm 3.49$ & 0.034 \\
\hline Vitamin C (mg) & $168.71 \pm 121.30$ & $197.25 \pm 203.97$ & $111.27 \pm 146.83$ & $183.99 \pm 288.26$ & $69.74 \pm 101.82$ & 0.338 \\
\hline Vitamin B12 (mcg) & $6.47 \pm 3.98$ & $2.16 \pm 0.80$ & $3.94 \pm 6.85$ & $7.66 \pm 9.26$ & $2.35 \pm 1.91$ & 0.302 \\
\hline Saturated FA (g) & $22.45 \pm 15.33$ & $17.57 \pm 9.70$ & $23.48 \pm 13.99$ & $24.78 \pm 25.91$ & $18.99 \pm 14.14$ & 0.691 \\
\hline $\begin{array}{l}\text { Monounsaturated } \\
\text { FA (g) }\end{array}$ & $17.94 \pm 10.77$ & $11.38 \pm 5.78$ & $19.02 \pm 10.42$ & $18.16 \pm 15.01$ & $16.93 \pm 10.77$ & 0.438 \\
\hline $\begin{array}{l}\text { Polyunsaturated } \\
\text { FA (g) }\end{array}$ & $9.03 \pm 4.53$ & $4.45 \pm 2.56$ & $9.68 \pm 4.11$ & $7.31 \pm 4.40$ & $10.25 \pm 5.78$ & 0.031 \\
\hline
\end{tabular}

TEV: total energy value; FA: fatty acids; SD: standard deviation; RE: retinol equivalents; aTE: alpha tocopherol equivalents. 
Food frequency is described in Figure 1, where it was observed that $48.5 \%(n=33)$ never consume snacks, $77.9 \%$ $(n=53)$ never consume fried egg, $51.5 \%(n=35)$ never consume French fries, $64.75(n=44)$ never consume other fried foods, $77.9 \%(\mathrm{n}=53)$ never consume sandwich cookies, $45.6 \%(n=31)$ never consume sweets, and $60.3 \%(n=41)$ never consume desserts. We also observed daily consumption of milk by $70.6 \%(\mathrm{n}=48)$, of fruit by $52.9 \%(\mathrm{n}=36)$, vegetables by $54.4 \%(\mathrm{n}=37)$, and of meat by $76.5 \%(\mathrm{n}=52)$.

Figure 2 shows the nutritional status of the population studied according to the classifications by age, so that normal weight was more frequent in all age groups.

\section{Discussion}

In this cross-sectional study, we observed that children and adolescents with DS have, in most cases, BMI suitable for age, when evaluated by specific curves for DS. With regard to eating habits, there was an adequate intake of nutrients according to the recommendations and association between BMI classification and intake of polyunsaturated fatty acids and vitamin $\mathrm{E}$.

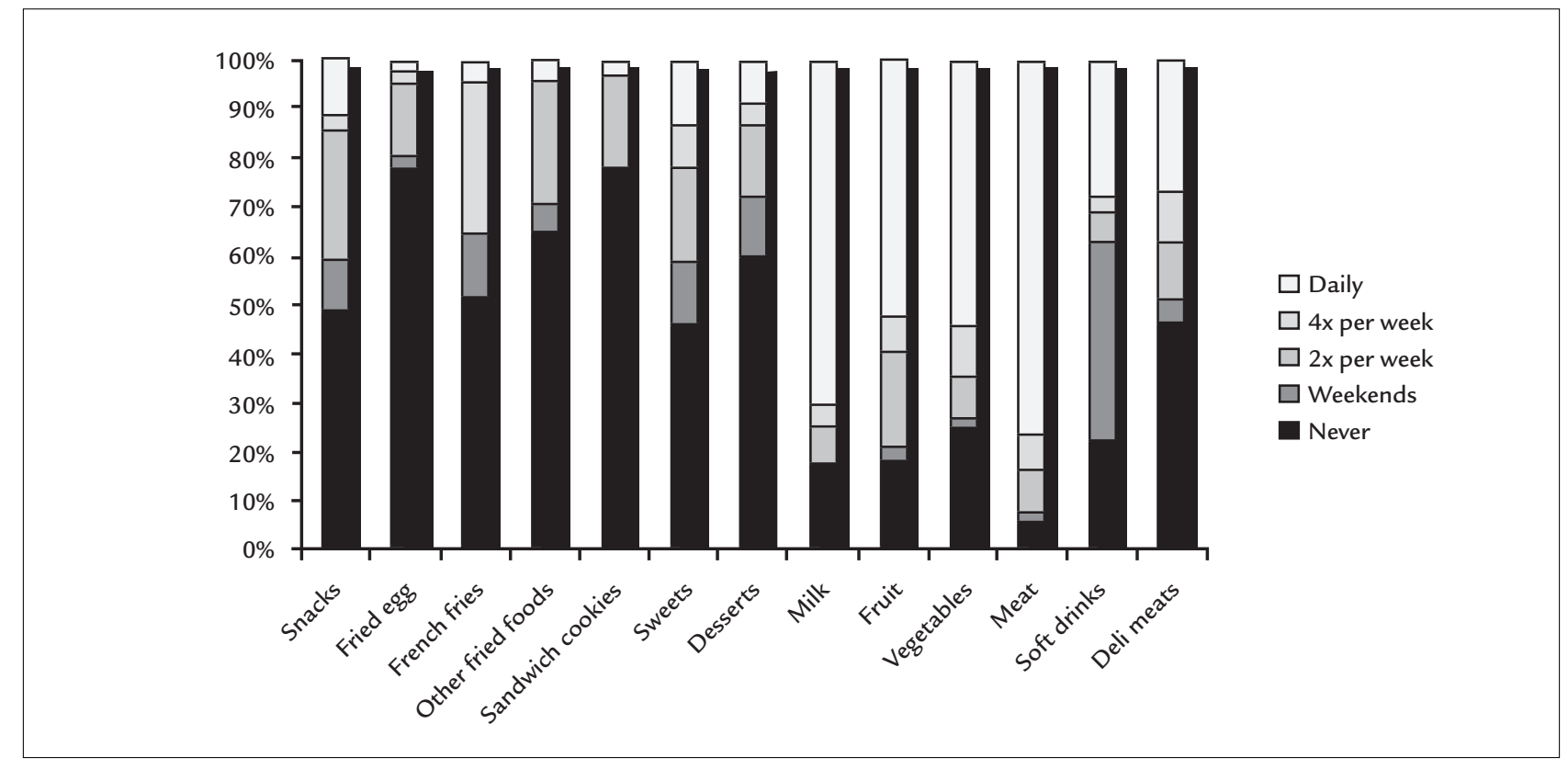

FIGURE 1 Distribution of food frequency.

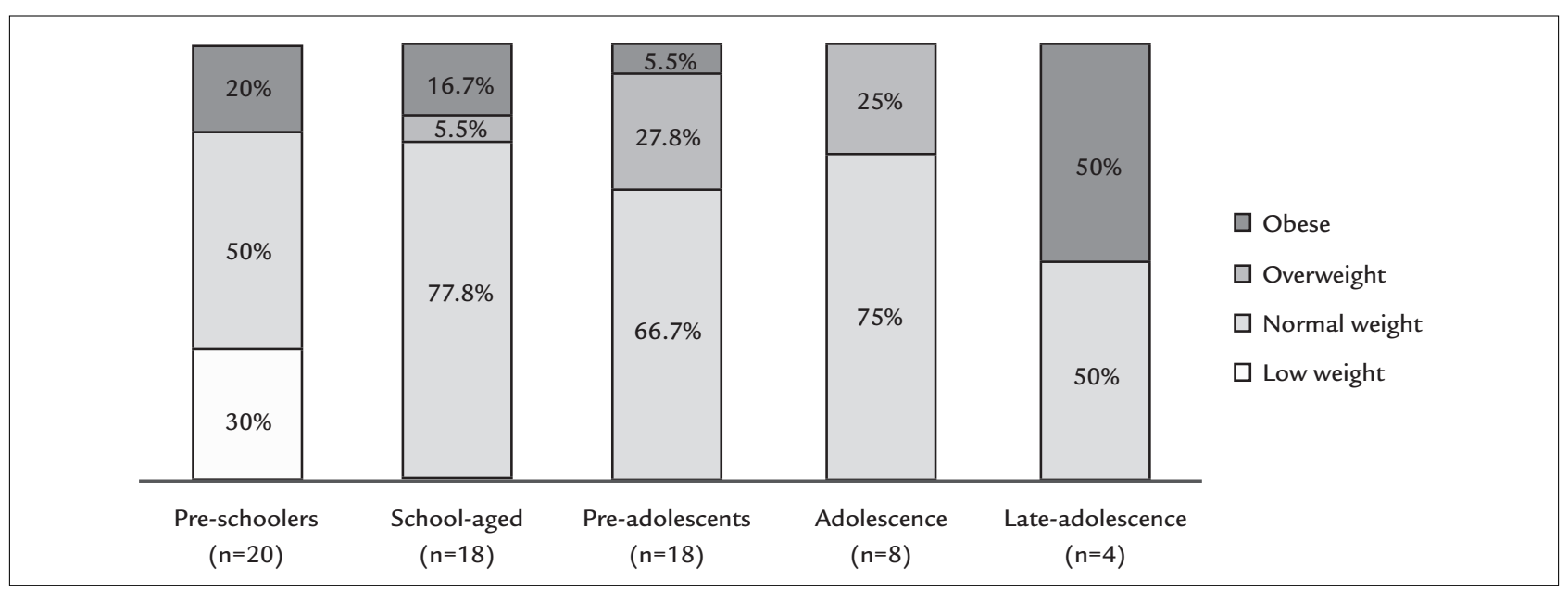

FIGURE 2 Nutritional status according to specific curves for DS. Pre-schoolers: 2 to 5 years; school-aged: 6 to 9 years; pre-adolescents: 10 to 14 years; adolescence: 15 to 17 years; late-adolescence: 18 to 19 years. 
The prevalence of overweight and obesity was lower than expected in this study comparing the BMI curves for age as recommended by the $\mathrm{WHO}^{11}$ and the curves specific for DS. ${ }^{4}$ We can raise some important aspects to understand these findings. First, the growth curves for DS take into account the smallest increase in weight and height and therefore the value of the BMI should be classified differently than the growth curves for children without DS. ${ }^{4,6}$

Even though BMI for gender and age is the method of choice for assessing nutritional status as recommended by the WHO, different studies ${ }^{14-16}$ only adopt weight/ age and height/age curves as proposed by Cronk et al. ${ }^{6}$ The prevalence of overweight in these studies varies between 16 and 30\%. In people with DS, the basal metabolic rate is significantly lower than that of individuals matched by age and gender without the syndrome. ${ }^{17}$ This may explain in part why people with DS are classified more often as overweight and/or obese.

For example, in our study, $85.3 \%$ of individuals classified as normal weight according to the curve specific for DS, would be $6.3 \%$ obese or $82.4 \%$ of overweight according to the WHO curves. In practice, in the absence of specific curves, or in the routine of professionals, when there are limitations to their use, it is important to monitor the growth and development of these children. If the curves used are those recommended by the WHO, it should be kept in mind that the interpretation will be different.

At the Pediatric Cardiology Clinic of Instituto de Cardiologia, patients with DS are also treated by nutritionists in order to primarily prevent cardiovascular risk factors. Therefore, these patients and caregivers can receive nutritional guidance to adopt eating habits healthier than those expected in the general population. ${ }^{18-20}$

Eating habits were adequate in this population. $\mathrm{Nu}$ trition education occurs in childhood, so it is important to offer a healthy diet, with the introduction of varied foods, appropriate for the age and development of children and adolescents. Thus, nutritional management is critical for young people who have cardiovascular risk factors such as obesity. Children and adolescents with this genetic abnormality should have a healthy diet, adapted to their clinical conditions. According to the data collected in our study based on a 24-hour record, most participants of both genders consume adequate amounts of carbohydrate, protein and lipids according to the Dietary Reference Intakes (DRI) recommendations. ${ }^{21}$

The prevalence of overweight and obesity in children with congenital heart disease was similar to that described in the literature for children with non-congenital disease.
In Brazil, the high prevalence of overweight in children and adolescents, in general, has been a cause for concern, because other risk factors for ischemic heart disease such as high blood pressure, glucose intolerance, dyslipidemia and sedentary lifestyle have emerged. These modifiable risk factors have been well discussed in the literature on children without heart disease. ${ }^{22}$

Vitamin E, which in this study was associated with the classification of BMI, is a fat-soluble antioxidant that occurs naturally. This micronutrient has been proposed for the prevention and protection of cardiovascular events. ${ }^{23-26}$ But although studies have 15 or more years of follow up, vitamin E supplementation in the primary and secondary prevention of acute myocardial infarction (AMI) and atherosclerosis has not yet demonstrated statistical difference between groups. ${ }^{23-26}$

Some limitations of this study should be considered. Since this is a cross-sectional study, without monitoring over time, it was not possible to establish a temporal relationship between eating habits and the presence of overweight in individuals with DS. In our study, in particular, the findings of healthy eating and normal macronutrient distribution among children and adolescents with DS can be explained as the awareness of the problem by families, with action taken towards habit changes. Rigorous clinical monitoring of this group of patients may have been an influence, although that cannot be directly stated based on the study. Thus, our data can contribute to the planning of new studies with follow-up over time or intervention.

Given the results of this study, the need for people with Down syndrome to receive unique attention from health teams is observed. Even though this study includes a small sample, we were able to demonstrate that children with this condition can present appropriate parameters, receiving a nutritionally adequate and balanced diet in terms of macro- and micronutrients, and being physically active. Encouraging health professionals to strengthen family members and/or legal guardians to seek proper monitoring of these children from birth, enabling adequate and healthy development, is essential for this to occur properly.

Our study reveals the need for an expanded and detailed assessment thus obtaining more reliable results and the proper interpretation of the nutritional status of these individuals, due to their unique growth and development. Thus, reviews on specific curves for DS would be the recommended practice for health professionals so as to avoid precipitated diagnosis of overweight and/or obesity in this population. 
The almost complete lack of national data, the relevance of the topic, and findings consistent with other studies show the importance of monitoring, thorough investigation and proper anthropometric assessment in patients with DS. Thus, the present findings can serve as a basis for planning studies of dietary intervention and/or physical activity, as well as planning of preventive measures.

\section{Conclusion}

The results of this study showed that children and adolescents with DS are mostly considered as normal weight for age when evaluated using BMI curves specific for DS, taking into account and highlighting the importance of a different interpretation for the growth and development of these individuals. With regard to eating habits, there was an adequate intake of nutrients according to the recommendations and association between BMI classification and intake of polyunsaturated fatty acids and vitamin E.

\section{ACKNOWLEDGMENTS}

We thank the IC-FUC/RS, for their support to the research project, our families, and the medical team at PREVINA (Pediatric Preventive Cardiology Clinic), without whom it would have been impossible to develop the study.

\section{Resumo}

Curvas de crescimento na síndrome de Down com cardiopatia congênita

Objetivo: avaliar hábitos alimentares, estado nutricional e frequência alimentar em crianças e adolescentes com síndrome de Down (SD) portadores de cardiopatia congênita (CC). Adicionalmente, procurou-se comparar classificações de índice de massa corpórea (IMC) de acordo com curvas da Organização Mundial da Saúde (OMS) e curvas desenvolvidas para indivíduos com SD.

Método: estudo transversal com indivíduos portadores de SD e CC atendidos em um centro de referência para cardiologia, com idade entre 2 e 18 anos. Foram aferidos peso, altura, IMC, valor energético total (VET) e frequência alimentar. $\mathrm{O}$ estado nutricional foi analisado por meio de IMC para gênero e idade, utilizando-se curvas específicas para SD e curvas da OMS.

Resultados: foram avaliados 68 indivíduos portadores de SD com CC. O defeito do septo atrioventricular (DSAV) foi a cardiopatia mais frequente $(52,9 \%)$. Houve diferen- ça de classificação do IMC entre as curvas propostas para portadores de SD e pela OMS. Houve associação entre consumo de vitamina $\mathrm{E}$ e ácidos graxos poli-insaturados. Conclusão: resultados mostraram que indivíduos com SD são, em sua maioria, considerados eutróficos para a idade quando avaliados pelas curvas específicas para SD. Avaliá-los de acordo com as curvas específicas para SD seria o recomendado para a prática dos profissionais da saúde, evitando-se diagnósticos precipitados de sobrepeso e/ ou obesidade nessa população.

Palavras-chave: síndrome de Down, avaliação nutricional, antropometria, índice de massa corporal.

\section{References}

1. De Onis M, Blössner M, Borghi E. Global prevalence and trends of overweight and obesity among preschool children. Am J Clin Nutr. 2010; 92(5):1257-64.

2. Luft VC, Mello ED. Síndrome de Down: supervisão em saúde, aspectos nutricionais e manejo. Revista Nutrição em Pauta. 2006; XIV(78):19-23.

3. Soares FA, Ávila e Lara M, Kowalski M. A longevidade na síndrome de Down. FIEP Bulletin On-line. 2009; 79(1)

4. Myrelid A, Gustafsson J, Ollars B, Annerén G. Growth charts for Down's syndrome from birth to 18 years of age. Arch Dis Child. 2002; 87(2):97-103.

5. Bravo-Valenzuela NJ, Passarelli ML, Coates MV, Nascimento LF. Weight and height recovery in children with Down syndrome and congenital heart disease. Rev Bras Cir Cardiovasc. 2011; 26(1):61-8.

6. Cronk C, Crocker AC, Pueschel SM, Shea AM, Zackai E, Pickens G, et al. Growth charts for children with Down syndrome: 1 month to 18 years of age. Pediatrics. 1988; 81(1):102-10

7. Monteiro FPM. Estado nutricional de crianças portadoras de cardiopatias congênitas: avaliação de medidas antropométricas [dissertation]. Fortaleza: Universidade Federal do Ceará; 2009.

8. Cunha AMFV, Blascovi-Assis SM, Fiamenghi Jr GA. Impacto da notícia da síndrome de Down para os pais: histórias de vida. Ciênc saúde coletiva. 2010; $15(2): 445-51$

9. Soar C. Índices antropométricos no diagnóstico de sobrepeso e obesidade de escolares de uma instituição pública de Florianópolis, SC [dissertation] Florianópolis: Universidade Federal de Santa Catarina; 2003.

10. Roieski IM, Lima e Silva I, Cardoso FB, Beresford H. Avaliação do perfil nutricional de adolescentes com síndrome de Down: pressuposto epistemológico para um aconselhamento nutricional com enfoque na ergomotricidade. Amazônia: Science \& Health. 2014; 2(2):21-8.

11. Ministério da Saúde. Curvas de Crescimento da Organização Mundial da Saúde - OMS. 2006/2007. Available from: http://dab.saude.gov.br/portaldab/ ape_vigilancia_alimentar.php?conteudo=curvas_de_crescimento.

12. Barbiero SM, Pellanda LC, Cesa CC, Campagnolo P, Beltrami F, Abrantes CC. Overweight, obesity and other risk factors for IHD in Brazilian schoolchildren. Public Health Nutr. 2009; 12(5):710-5.

13. Trumbo P1, Schlicker S, Yates AA, Poos M; Food and Nutrition Board of the Institute of Medicine, The National Academies.. Dietary reference intakes for energy, carbohydrates, fiber, fat, fatty acids, cholesterol, protein and amino acids. J Am Diet Assoc. 2002; 102(11):1621-30.

14. Lopes Tde S, Ferreira DM, Pereira RA, Veiga GV, Marins VM. Assessment of anthropometric indexes of children and adolescents with Down syndrome. J Pediatr (Rio J). 2008; 84(4):350-6.

15. Chumlea WC, Cronk CE. Overweight among children with trisomy 21. J Intellect Disabil Res.1981; 25(4):275-80.

16. Zini B, Ricalde SR. Características nutricionais das crianças e adolescentes portadoras de síndrome de Down da APAE de Caxias do Sul e São MarcosRS. Pediatria. 2009; 31(4):252-9.

17. Granzotti JA, Paneto IL, Amaral FT, Nunes MA. [Incidence of heart defects in Down syndrome]. J Pediatr (Rio J).1995; 71(1):28-30. 
18. Akabas SR, Chouinard JD, Bernstein BR. Nutrition and physical activity in health promotion and disease prevention: potential role for the dental profession. Dent Clin North Am. 2012; 56(4):791-808.

19. Simões LRC. Avaliação nutricional e antropométrica de crianças de 06 e 36 meses, com síndrome de Down, e oferta de oficinas de culinária à suas famílias-Fundação Dom Bosco-BH. Sepex - Semana de Pesquisa e Extensão do Uni - BH 2007; IV; 30-7.

20. González-Agüero A, Vicente-Rodríguez G, Gómez-Cabello A, Ara I, Moreno LA, Casajús JA. A combined training intervention programme increases lean mass in youths with Down syndrome. Res Dev Disabil. 2011; 32(6):2383-8.

21. Shabayek MM. Assessment of the nutritional status of children with special needs in Alexandria: I. Nutrient intake and food consumption. J Egypt Public Health Assoc. 2004; 79(3-4):225-41.

22. Barbiero SM, D'Azevedo Sica C, Schuh DS, Cesa CC, de Oliveira Petkowicz R, Pellanda LC. Overweight and obesity in children with congenital heart disease: combination of risks for the future? BMC Pediatr. 2014; 14:271.
23. Vardi M, Levy NS, Levy AP. Vitamin E in the prevention of cardiovascular disease: the importance of proper patient selection. J Lipid Res. 2013 54(9):2307-14.

24. Virtamo J, Rapola JM, Ripatti S, Heinonen OP, Taylor PR, Albanes D, et al. Effect of vitamin $\mathrm{E}$ and beta carotene on the incidence of primary nonfatal myocardial infarction and fatal coronary heart disease. Arch Intern Med. 1998; 158(6):668-75.

25. Sacco M, Pellegrini F, Roncaglioni MC, Avanzini F, Tognoni G, Nicolucci A; PPP Collaborative Group. Primary prevention of cardiovascular events with low-dose aspirin and vitamin $\mathrm{E}$ in type 2 diabetic patients: results of the Primary Prevention Project (PPP) trial. Diabetes Care. 2003 26(12):3264-72.

26. DeMaio SJ, King SB 3rd, Lembo NJ, Roubin GS, Hearn JA, Bahagavan HN, et al. Vitamin E supplementation, plasma lipids and incidence of restenosis after percutaneous transluminal coronary angioplasty (PTCA). J Am Coll Nutr.1992; 11(1):68-73. 